\title{
Antioxidant effects of hydro-alcoholic extract of Ashrasi date palm in hepatotoxicity caused by mercuric chloride administration
}

\author{
Shiva Roshankhah ${ }^{1}$, Ahmad Shabanizadeh ${ }^{2}$, Amir Abdolmaleki ${ }^{1}$, Mohammad Reza Salahshoor ${ }^{1}{ }^{*}$
}

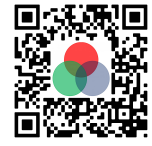

Use your smartphone to scan this QR code and download this article

${ }^{1}$ Department of Anatomical Sciences, Medical School, Kermanshah University of Medical Sciences, Kermanshah, Iran

${ }^{2}$ Department of Anatomical Sciences, School of Medicine, Immunology of Infectious Diseases Research Center, Rafsanjan University of Medical Sciences, Rafsanjan, Iran

\section{Correspondence}

Mohammad Reza Salahshoor Department of Anatomical Sciences, Medical School, Kermanshah University of Medical Sciences, Kermanshah, Iran

Email: reza.salahshoor@yahoo.com

\section{History}

- Received: Apr 22, 2020

- Accepted: Jun 08, 2020

- Published: Jun 28, 2020

DOI : 10.15419/bmrat.v7i6.613

\section{Check for updates}

\section{Copyright}

(c) Biomedpress. This is an openaccess article distributed under the terms of the Creative Commons Attribution 4.0 International license.

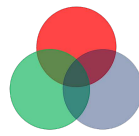

\section{INTRODUCTION}

The application of the secondary defense system, such as antioxidant agents, can eliminate inflicted cellular injuries. Moreover, plant-based antioxidant elements have excellent therapeutic properties ${ }^{1}$. They also have minor harmful side effects on cells. The date palm (Phoenix dactylifera) belongs to the Arecaceae family, which consists of 2,500 species and is generally cultivated for the consumption of its fruit ${ }^{2}$. There is increasing evidence regarding anti-bacterial, antiinflammatory, immunomodulatory, and anti-tumor effects of date palm ${ }^{3}$. Vayalil et al. stated that the concentrations of 4.5 and $9 \mathrm{mg} / \mathrm{ml}$ of ADP extract could effectively repress hydroxyl radicals and superoxides, respectively ${ }^{4}$. Its powerful antioxidant activity can be credited to the phytochemical compounds, such as carotenoids, flavonoids and phenolic acids, in addition to the ferulic acid, phytosterols, and phytoestrogens found within it ${ }^{5}$.

The ADP is cultivated in the Kermanshah Region of West Iran and is used for treating many illnesses such as fever, bronchitis, intestinal ailments, and wound healing in the Kurdish traditional medicine.

Enhanced reactive oxygen species (ROS) accumulation in the body induces lipid peroxidation (LP) occurrence and secretion of inflammatory cytokines, as well as increases nitric oxide (NO) production in various tissues ${ }^{6}$. LP is the main element involved in oxidative injury of lipid structures, lipoproteins, and cell membranes ${ }^{7}$. The cellular LP process causes the generation and accumulation of hydroxides and peroxides, which are the basis of cell toxicity and reduced function of antioxidant enzymes in the body ${ }^{8}$.

Mercuric chloride (MC), i.e. $\mathrm{HgCl}_{2}$, is composed of chlorine and mercury ${ }^{9}$. MC has a yellowish or bright white color and has been extensively studied in chemistry laboratories. It has also been used for syphilis treatment. However, today, it is not consumed anymore due to mercury poisoning ${ }^{10}$. MC damages the cells, DNA and cell membrane, leading to cell death ${ }^{11}$. Some elements, such as increased levels of inflammatory cytokines, ROS and NO, are 
thought to complicate the harmful effects of $\mathrm{MC}^{12}$. Exposure to MC causes oxidative stress production (such as $\mathrm{H}_{2} \mathrm{O}_{2}$ and $\mathrm{OH}$ ), stimulation of cell destruction (through interference with cellular metabolism), and membrane lipid damage ${ }^{13}$. The oxidative stress caused by LP leads to cell membrane damage of hepatocytes and activation of liver enzymes ${ }^{14}$.

Due to the various antioxidant properties of ADP and the limited reports in the literature regarding ADP's protective effects on liver degeneration caused by MC, this study was designed to evaluate the potential antioxidant and protective effects of the hydro-alcoholic extract of ADP on hepatotoxicity caused by MC administration.

\section{MATERIALS - METHODS}

\section{Animals}

In this in vivo experimental study, 56 male rats (Wistar rats, 20-250 g, 8-weeks old) were purchased from the specialized and experimental research center of laboratory animals (Pasteur, Tehran, Iran). The animals were kept in cages under standard animal conditions, including optimal temperature $\left(22 \pm 2{ }^{\circ} \mathrm{C}\right)$, relative humidity (25 - 35\%), and $12 / 12 \mathrm{~h} \mathrm{light/dark}$ cycle, with free access to standard pellet and water. The animals were treated according to ethical standards; the University Ethics Committee approved all experimental procedures for the care and use of animals (IR.KUMS.REC. 1394.0154).

\section{Plant collection}

The fresh fruits of the Ashrasi date palm were collected in the month of August 2019 from the local areas of Ghasreshirin, Kermanshah (Iran). They were authenticated by Dr. F. Firozian, Department of Botany, H. U. M Institute, Hamadan (Iran). The plant specimen was deposited at H. U. M Institute with voucher number (NO: 2262) for further reference.

\section{Preparation of ADP extract}

ADP fruit was dried in the dark (for 3 weeks) and coarsely pulverized before extraction. Then, $200 \mathrm{~g}$ of powdered plant material was placed in $2 \mathrm{~L}$ (1-10 $\mathrm{wt} / \mathrm{vol}$ ) of $70 \%$ ethanol and kept in a $38^{\circ} \mathrm{C}$ water bath for 3 hours and cooled simultaneously. It was exposed to ambient temperature for $12 \mathrm{~h}$. The solution was filtered through Whatman filter paper and the resultant material was concentrated under reduced pressure using a rotary evaporator. This extract was kept at -20 ${ }^{o} \mathrm{C}$ until use ${ }^{6}$.

\section{Phytochemical screening}

Semi-quantitative phytochemical screening of the Ashrasi date palm (ADP) extract was carried out by the protocols and procedures described by Treas and Evans $^{15}$.

\section{Experimental protocols}

The 56 rats were randomly divided into 8 groups ( $\mathrm{n}=$ 7 per group). The first group (control group) received normal saline (in the same volume as the treatment groups). The second group (MC group) received a single dose of MC (50 mg/kg) intraperitoneally. The third to fifth groups (ADP administration) received ADP extract at the doses of 30,90 , and $270 \mathrm{mg} / \mathrm{kg}$ orally, respectively (once a day for 5 weeks). The sixth to eight groups (MC+ADP) received a single dose of MC $(50 \mathrm{mg} / \mathrm{kg})$ in order to induce liver damage, followed by administration of ADP extract at the doses of 30,90 , and $270 \mathrm{mg} / \mathrm{kg}$ orally for 5 weeks ${ }^{2,14}$.

\section{Dissection of tissue samples}

The animals were anesthetized and killed with ether inhalation, $24 \mathrm{~h}$ after the last treatment. Blood samples of all groups were collected. Five $\mathrm{ml}$ of the blood sample was aspirated from the right ventricle and allowed to clot for $20 \mathrm{~min}$ at $37^{\circ} \mathrm{C}$. The serum separation was then conducted by centrifugation at 4,000 rpm for $10 \mathrm{~min}$. The sera were stored at $-70^{\circ} \mathrm{C}$ until analysis. The liver tissues were dissected and a fragment of the liver $\left(1 \times 1 \mathrm{~mm}^{3}\right)$ was fixed in $10 \%$ formalin solution for morphometric and histological examinations ${ }^{6}$.

\section{Apoptosis assay}

The DeadEnd Colorimetric TUNEL test was performed according to the manufacturer's instructions (Promega Inc., Madison, WI, USA). Briefly, paraffinembedded blocks were prepared using an automatic tissue processor. Five- $\mu \mathrm{m}$ histological slices were cut through a microtome (Leica, Germany), and 5 tissue slices per rat were selected. The tissues were subjected to deparaffinization. After deparaffinization, the liver sections were fixed again in $4 \%$ formaldehyde. The slices were then stained with diaminobenzidine (DAB) with chromogen horseradish peroxidase, and then incubated with diaminobenzidine substrate and counterstained with hematoxylin. The positive hepatocytes were visualized and counted under a light microscope ${ }^{16}$. 
Histopathological and morphometric evaluation

To assess histological alterations, a section of the right lobe of the liver was fixed in $10 \%$ formalin. The tissues were then fixed in paraffin and thin sections $(4 \mu \mathrm{m})$ were prepared using a microtome (Leica RM 2125, Germany). The slices were then stained with hematoxylin and eosin. Thereafter, some morphological assessments including full cellular area, hepatocyte outline, maximum and minimum axis, mean axis, and central hepatic vein $(\mathrm{CHV})$ were determined by a light microscope at $40 \times$ magnification. At least 50 cells from the separate region were measured to eliminate the probable measurement bias. The cells were visualized with a microscope coupled to an ADP12 Camera (3.34 million pixel resolution), and with the use of the Olysia Bio-software (Olympus Optical Co. LTD, Tokyo, Japan) ${ }^{16}$.

\section{RNA isolation and real-time PCR}

The expression level of apoptotic genes p53 (F: 5'-AAGCTCATTTCCTGGTATG-3'; R: 5'CTGCCACAAGAACTAGAGA-3'), Bcl2 (F: 5'-TGGGATGCCTTTGTGGAACT-3'; R: 5'GAGACAGCCAGGAGAAATCA-3'), and Bax (F: 5'-ATGGCGAAATGGAGATGAATA-3'; R: 5'-GCATGGGCATCCTTTAACTC-3') were examined using real-time polymerase chain reaction (PCR). All liver tissues were stored in the freezer $\left(-80^{\circ} \mathrm{C}\right)$ to prevent tissue degeneration. Total RNA content of liver tissue was extracted using the RNeasy mini kit (Qiagen Co., Germantown, $\mathrm{MD})$. The cDNA was synthesized from the total RNA extraction by RevertAid ${ }^{\mathrm{TM}}$ First Strand cDNA Synthesis Kit, according to the manufacturer's recommendations (Fermentas, Vilnius, Lithuania). In addition, the DNA samples were treated using a DNase kit (Qiagen). The expression level of apoptotic genes was measured through glyceraldehyde-3-phosphate dehydrogenase primer (F: 5'-AAGCTCATTTCCTGGTATG-3'; R: 5'CTGCCACAAGAACTAGAGA-3') as the endogenous control (by SYBR Green through a comparative method ${ }^{17}$.

\section{Determination of NO levels}

The Griess method based on colorimetric approaches was employed to measure the NO levels. Fivehundred $\mu \mathrm{L}$ of serum was deproteinized with zinc sulfate $(10 \mathrm{mg})$. After centrifugation $(3,000 \mathrm{rpm}, 10$ $\min )$ the equal amounts of Griess reagent (1\% sulfanilamide, $0.1 \%$ naphtylenediamide in $2.5 \%$ phosphoric acid) were also added to the supernatant in 96well ELISA plates and incubated for $10 \mathrm{~min}$ at $37^{\circ} \mathrm{C}$.
The absorbance was set at $450 \mathrm{~nm}$ with the use of a microplate reader. Nitric concentrations were calculated from a sodium nitric standard curve ${ }^{8}$.

\section{LP levels}

The level of molecular reaction between thiobarbituric acid (TBA) and malondialdehyde (MDA) following the colorimetry process was considered as the measurement of LP levels. The TBA test determines MDA generated from the oxidation of fatty acids. The frozen sample of the liver tissue was used. First, the tissue was washed with phosphate-buffered saline (PBS; pH 7). Then, the tissue was homogenized by an ultrasonic homogenizer in a cold phosphate buffer containing ethylene diamine tetra acetic acid (EDTA). Twenty $\mu$ l of supernatant was mixed in the test tubes. Each test tube contained $4 \mu \mathrm{l}$ of butylated hydroxytoluene, $20 \mu \mathrm{l}$ of phosphoric acid (1M), and $20 \mu \mathrm{l}$ of TBA solution. The test tube was incubated for $60 \mathrm{~min}$ at $70^{\circ} \mathrm{C}$, followed by centrifugation $(10,000 \mathrm{rpm}, 4$ min). Next, $80 \mu \mathrm{l}$ of the supernatant was poured into the spectrophotometer tubes. The produced dye in the commercial kit was read at $532 \mathrm{~nm}$ and the MDA level was calculated in $\mathrm{nmol} / \mathrm{mg}$ protein ${ }^{16}$.

\section{FRAP technique}

The total antioxidant capacity (TAC) of the serum was analyzed by the Ferric Reducing Ability of Plasma (FRAP) technique based on the ability of the plasma to reinstate the ferric. The FRAP substance was consisted of $30 \mathrm{~mL}$ of acetate buffer (Sigma-Aldrich, Louis St., MO) and $1.5 \mathrm{~mL}$ ferric chloride (SigmaAldrich, Louis St., MO). Sequential concentrations of ferric sulfate (Sigma-Aldrich, Louis St., MO) were used as an external ${ }^{17}$.

\section{Hepatic enzyme measurements}

The liver homogenate was centrifuged twice $(12,000$ $\mathrm{rpm}, 10 \mathrm{~min}$ ). Then, the supernatant was used for the measurement of hepatic enzymes, including Aspartate Aminotransferase (AST), Alanine Aminotransferase (ALT), and Alkaline Phosphatase (ALP). The ALT and AST were tested based on Reitman and Frankel biochemical methods. The ALP protocol was also determined according to the technique which was set out in the practical research laboratory ${ }^{6}$.

\section{Evaluation of inflammation cytokines}

The enzyme-linked immunosorbent assay (ELISA) method was used to assess the Toll-like receptor 4 (TLR4) secretion (MyBioSource, California, USA), 
interleukin-1 beta (IL-1 $\beta$ ) secretion (Abcam Cambridge, UK), and tumor necrosis factor-alpha (TNF$\alpha)$ (Abcam, Cambridge, UK) production by the liver. The total proteins of the extracted livers were lysed by RIPA (Abcam, Cambridge, UK) and centrifuged at $15,000 \mathrm{~g}$ for $30 \mathrm{~min}$. The ratio of 1:20 supernatants/dilutions were seeded into coated microplates with antibodies to induce enzyme-substrate reaction. Standard solutions were used for drawing the standard curves. The amounts of proteins were examined in supernatant fractions by ELISA kits. The rate of absorbance was measured in triplicate at $450 \mathrm{~nm}^{17}$.

\section{Statistical analysis}

The Kolmogorov-Smirnov examination was conducted to confirm the normal distribution of the data. One-way analysis of variance (ANOVA) and Tukey post-hoc test were applied to obtain statistical analysis and differences among the groups, respectively. The statistical software package of SPSS (Chicago, IL, USA) was used for data analysis. The final outcomes were expressed as mean \pm standard error, and $p<0.05$ was considered as significant.

\section{RESULTS}

\section{Phytochemical screening}

The phytochemical screening revealed 11 biochemical compounds in the ADP extract, and that dodecanoic acid, methyl ester and 9-octadecenoic acid are the peak compounds in this herb (Table 1).

\section{Apoptotic index}

The apoptotic index (AI) was significantly higher in the MC group compared to the control group $(P<$ 0.05). No significant differences were found in the AI of all ADP groups, when compared to the control group $(P>0.05)$. Furthermore, the doses of ADP in $\mathrm{ADP}$ and $\mathrm{MC}+\mathrm{ADP}$ groups correlated with a significant decline in the AI, as compared to the MC group $(P<0.05)$ (Figure 1).

\section{Morphometric examination}

In the experimental groups, a significant incremental effect was detected in the mean diameter of hepatocytes and the $\mathrm{CHV}$ among the control and $\mathrm{MC}$ groups $(P<0.05)$. Also, for $\mathrm{HD}$ and $\mathrm{CHV}$, no significant variations were observed histologically in the ADP groups as compared to the control group $(P>$ 0.05). Additionally, ADP significantly reduced the $\mathrm{HD}$ and $\mathrm{CHV}$ in all treated members of the ADP and $\mathrm{MC}+\mathrm{ADP}$ groups, when compared to the MC group $(P<0.05)$ (Figure 2).

\section{Histopathological modifications}

According to the findings based on histological assessments, the normal liver structure changed in the $\mathrm{MC}$ control and ADP treatment groups. Following $\mathrm{MC}$ administration in the MC group, the liver showed significant histological alterations and hepatic damages, including an increase in rate of irregularities, hepatocyte destruction, dilatation of hepatic sinusoidal space, hyperemia, and vacuolization of hepatocytes. Treatment with MC+ADP in all doses reduced the hepatic injury caused by MC administration (Figure 3).

\section{Gene expression levels}

Up-regulation of apoptotic p53 and Bax expression and down regulation of $\mathrm{Bcl} 2$ expression were detected in the group treated with MC; compared to the control group, the changes in expression levels were significant $(\mathrm{p}<0.05)$. Also, a significant down regulation of $p 53$ and Bax genes and up-regulation of $B c l 2$ apoptotic gene was similarly was detected in all doses of the ADP-treated and ADP+MC treated groups, as compared to the MC group (Figure 4).

\section{Hepatic levels of FRAP, LP and serum level of NO}

In the MC group, the FRAP levels were significantly lower than the control group $(P<0.05)$. Also, in the groups treated with $\mathrm{ADP}$ and $\mathrm{MC}+\mathrm{ADP}$, the FRAP levels were considerably elevated as compared to the MC group $(P<0.05)$, due to the ADP administration. Due to its detrimental effects, MC significantly increased the NO and LP levels in the MC group, compared with the control group $(P<0.05)$. It was also found that all doses of ADP extract could significantly reduce the mean levels of serum $\mathrm{NO}$ and LP in the $\mathrm{ADP}$ and $\mathrm{MC}+\mathrm{ADP}$ groups, as compared to the MC group $(P<0.05)$ (Table 2$)$.

\section{Levels of liver enzyme activity}

MC administration led to a significant increase in levels of key liver enzymes (e.g. Alanine Aminotransferase (ALT), Aspartate Aminotransferase (AST), and Alkaline Phosphatase (ALP)), in comparison with the control group $(P<0.05)$. As well, no significant differences were found in the mean concentrations of ALT, AST and ALP enzymes in all ADP-treated groups compared to the control group $(P>0.05)$. Moreover, whole various doses of ADP in the ADP-treated and $\mathrm{MC}+\mathrm{ADP}$ treated groups induced a significant decline in the mean concentration of hepatic enzymes, as compared to the MC group $(P<0.05)$ (Table 3). 
Table 1: Phytochemical screening of hydroalcholic extracts of ADP

\begin{tabular}{lc}
\hline Phytochemical tests & Extract \\
\hline 9-Octadecenoic acid (Z), methyl ester & ++ \\
Hexadecanoic acid, methyl ester & + \\
N-Butyl laurate & + \\
Octanoic acid- methylester & + \\
Pentanoic acid, 4-oxo-methylester & ++ \\
Dodecanoic acid, methylester & + \\
Decanoic acid, methylester & + \\
9,12-Octadecadienoic acid, methylester & + \\
Octadecanoic acid, methylester & + \\
Phenol, 2,6-bis (1,1-dimethylethyl-4-methy)l) & + \\
\hline
\end{tabular}

+: Mild presence, ++: Strong presence, ADP: Ashrasi Date palm

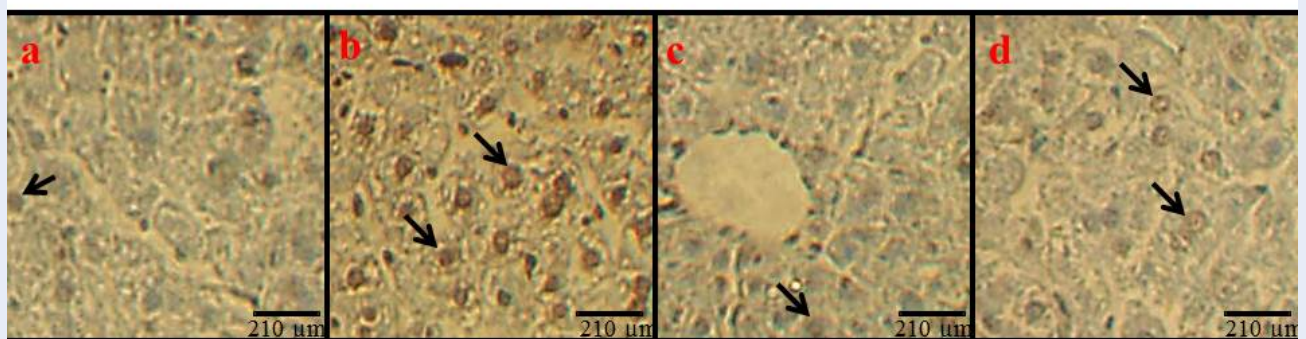

e

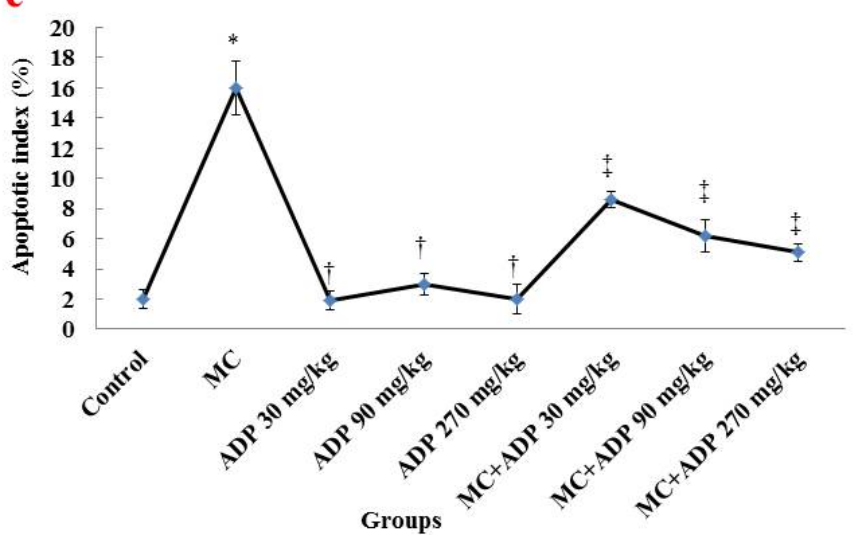

Figure 1: Apoptotic induction (a-d) and index (e). Apoptosis induction (a-d) (200× magnifications, TUNEL staining): control group (a), MC group (50 mg/kg) (b), ADP group ( $270 \mathrm{mg} / \mathrm{kg}$ ) (c) and ADP ( $270 \mathrm{mg} / \mathrm{kg})+\mathrm{MC}(50 \mathrm{mg} / \mathrm{kg})$ group (d). Black arrows refer to apoptotic cells. Apoptotic index (e): *Significant difference to the control group $(P<0.05)$. + Significant difference to the $M C$ group $(P<0.05)$. $¥$ Significant difference to the $M C$ group $(P<0.01)$ (scale bars: black $=210 \mu \mathrm{m}$ ). Abbreviations: MC: Mercuric chloride, ADP: Ashrasi Date palm. 


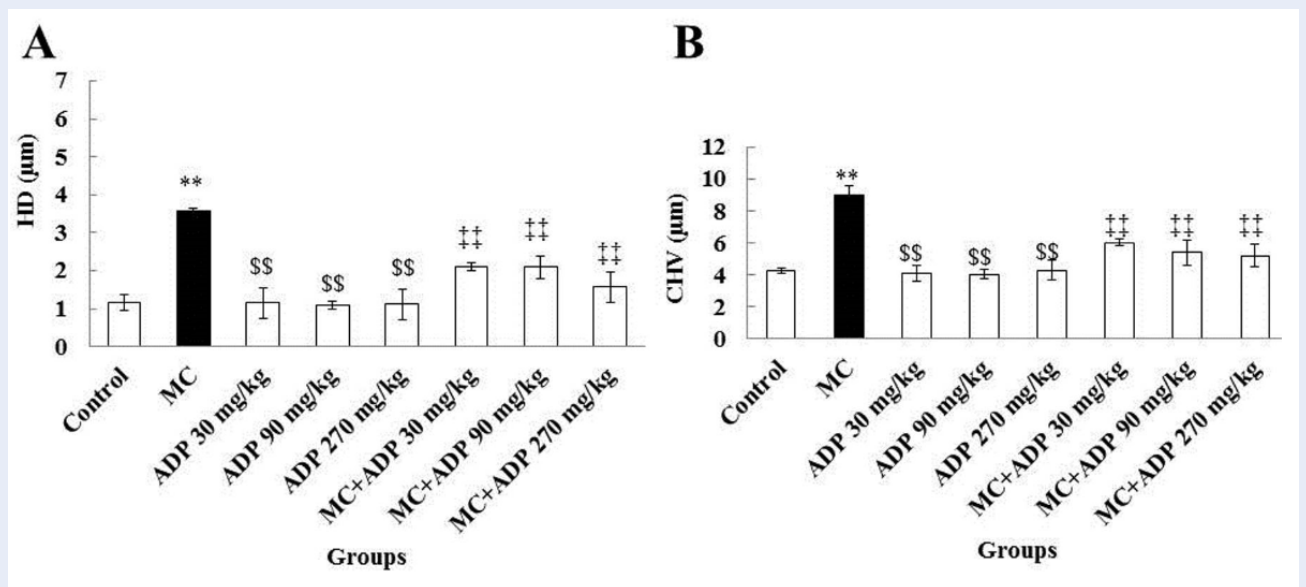

Figure 2: Morphometric alterations of MC and ADP on HD (A) and CHV (B). ${ }^{* *}$ Significant difference as compared to the control group $(P<0.05)$. ${ }^{\$}$ Significant difference as compared to the $M C$ group $(P<0.05)$. Significant difference as compared to the MC group $(P<0.05)$. Abbreviations: $\mathbf{C H V}$ : Central hepatic vein, HD: Hepatocyte diameter, MC: Mercuric chloride, ADP: Ashrasi Date palm.

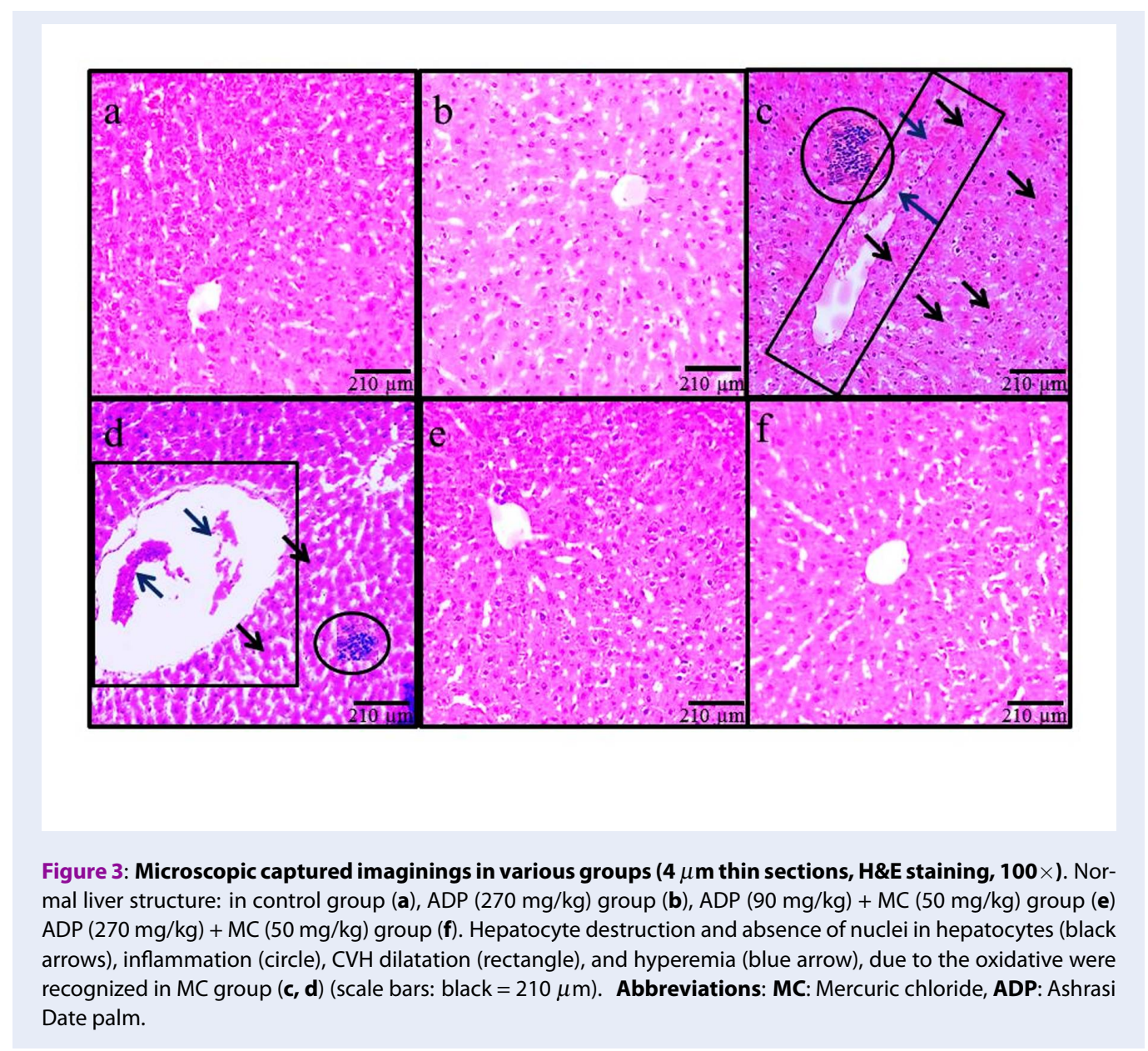




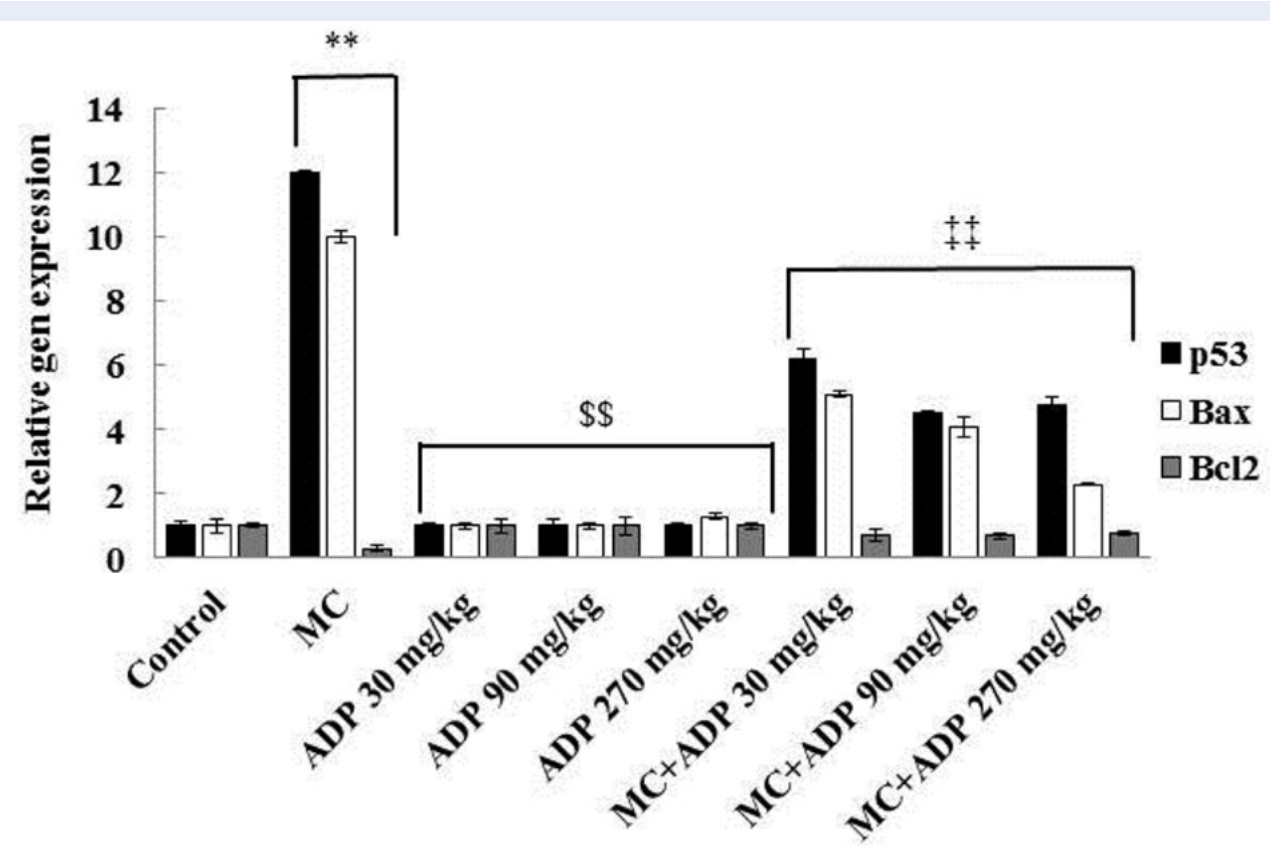

\section{Groups}

Figure 4: Therapeutics properties of MC and ADP on $p 53, B C / 2$ and $B a x$ genes expression of liver. ${ }^{* *}$ Statistically significant $(P<0.05)$ between $M C$ and control group, fłstatistically significant $(P<0.05)$ in $M C$ and $M C+A D P$ groups. ${ }^{\$}$ Significant modifications in ADP groups as compared to the MC group $(P<0.01)$. Abbreviations: MC: Mercuric chloride, ADP: Ashrasi Date palm.

Table 2: Effect of MC and ADP on antioxidant parameters and Al in male rats ( $n=7$ for each group)

\begin{tabular}{lcccc}
\hline Groups & NO $(\mathrm{mmol} / \mathrm{ml})$ & FRAP $(\mathrm{mmol} / \mathrm{ml})$ & $\mathrm{LP}(\mathrm{nmol} / \mathrm{mg})$ & AI \\
\hline Control & $42.36 \pm 3.8$ & $155.44 \pm 5.3$ & $2.04 \pm 0.06$ & $3.4 \pm 0.2$ \\
MC $50 \mathrm{mg} / \mathrm{kg}$ & $164.85 \pm 6.1^{*}$ & $63.53 \pm 4.1^{*}$ & $6.62 \pm 0.09^{*}$ & $16.8 \pm 2.5^{*}$ \\
ADP $30 \mathrm{mg} / \mathrm{kg}$ & $39.04 \pm 2.3$ & $159.05 \pm 7.6$ & $2.97 \pm 0.02$ & $1.9 \pm 0.2$ \\
ADP 90 mg/kg & $41.77 \pm 4.7$ & $151.75 \pm 5.9$ & $1.72 \pm 0.07$ & $3.1 \pm 0.1$ \\
ADP 270 mg/kg & $42.85 \pm 4.2$ & $154.77 \pm 6.3$ & $2.11 \pm 0.05$ & $2.9 \pm 0.3$ \\
ADP+MC 30 mg/kg & $89.9+32 \pm 5.4$ & $99.17 \pm 3.8$ & $4.55 \pm 0.1$ & $8.4 \pm 1.1$ \\
ADP+MC 90 mg/kg & $82.41 \pm 5.3$ & $102.43 \pm 7.2$ & $3.16 \pm 0.02$ & $6.4 \pm 1.2$ \\
ADP+MC 270 mg/kg & $82.37 \pm 4.1$ & $100.81 \pm 5.2$ & $3.73 \pm 0.5$ & $5.2 \pm 0.8$ \\
\hline
\end{tabular}

Data are presented as mean \pm SEM. ${ }^{*} \mathrm{P}<0.05$ compared to the control group. $\mathrm{P}<0.05$ compared to MC group. $\mathrm{P}<0.01$ compared to the MC group.

Abbreviations: AI: Apoptotic index, MC: Mercuric chloride, ADP: Date palm, NO: Nitric oxide, FRAP: Ferric reducing the ability of plasma, LP: Lipid peroxidation. 
Table 3: Effect of MC and ADP on the liver enzymes in male rats ( $n=8$ for each group)

\begin{tabular}{lccc}
\hline Groups & AST (ng/ml) & ALT $(\mathrm{ng} / \mathrm{ml})$ & ALP $(\mathrm{ng} / \mathrm{ml})$ \\
\hline Control & $151.22 \pm 7.3$ & $46.74 \pm 4.4$ & $172.85 \pm 6.8$ \\
MC $50 \mathrm{mg} / \mathrm{kg}$ & $298.72 \pm 6.2^{*}$ & $115.25 \pm 6.2^{*}$ & $499.13 \pm 7.1^{*}$ \\
ADP $30 \mathrm{mg} / \mathrm{kg}$ & $153.37 \pm 8.5$ & $42.34 \pm 2.4$ & $175.07 \pm 8.6$ \\
ADP $90 \mathrm{mg} / \mathrm{kg}$ & $150.82 \pm 6.6$ & $48.02 \pm 5.6$ & $175.77 \pm 7.1$ \\
ADP $270 \mathrm{mg} / \mathrm{kg}$ & $151.15 \pm 7.1$ & $47.75 \pm 3.8$ & $173.13 \pm 5.3$ \\
ADP +MC $30 \mathrm{mg} / \mathrm{kg}$ & $182.97 \pm 8.4$ & $66.34 \pm 6.3$ & $211.03 \pm 8.5$ \\
ADP +MC 90 mg/kg & $178.64 \pm 5.1$ & $62.81 \pm 5.7$ & $191.78 \pm 7.8$ \\
ADP +MC $270 \mathrm{mg} / \mathrm{kg}$ & $178.33 \pm 7.8$ & $60.82 \pm 3.3$ & $189.23 \pm 4.6$ \\
\hline
\end{tabular}

Data are presented as mean \pm SEM. ${ }^{*} \mathrm{P}<0.01$ compared to the control group. $\mathrm{P}<0.01$ compared to MCgroup. $\mathrm{P}<0.01$ compared to the MC group.

Abbreviations: MC: Mercuric chloride, ADP: AshrasiDate palm, AST: Aspartate Aminotransferase, ALT: AlanineAminotransferase, ALP: Alkaline Phosphatase.

\section{Inflammatory cytokines}

Inflammatory cytokines were significantly increased in the MC group compared to the control group ( $P$ $<0.05)$. No significant differences were found with the respect to the production of inflammatory cytokines in all ADP-treated groups, when compared to the control group $(P>0.05)$. Additionally, whole several doses of ADP in the ADP and MC+ ADP groups induced a significant decline in the inflammation cytokines as compared to the MC group $(P<$ 0.05) (Table 4).

\section{DISCUSSION}

The current study demonstrates that MC administration in adult male rats can cause dysfunction in the pancreas, while administration of the hydroalcoholic extract of ADP can successfully diminish these complications due to the strong antioxidant properties of ADP. The most vital tissue complicated in the organization of whole-body metabolism is the liver ${ }^{6}$. Thus, in this study we assessed the toxic effects of MC on hepatocytes, alteration of inflammatory factors, oxidative injury, and apoptotic changes. Moreover, for the first time, the therapeutic antioxidant and protective properties of ADP on hepatic injury were investigated.

As a new finding, in the present study, we discovered that ADP administration led to decreased levels of apoptotic cells and decreased gene expression of Bax and p53, but increased expression of Bcl2. P53 makes the mitochondrial membrane permeable to the influx of cytochrome-c into the intracellular matrix. Accordingly, $p 53$ adjusts the function of apoptotic elements such as Caspase and $\mathrm{Bax}^{18}$. As cell death was observed in hepatocytes, this suggests that MC has upregulation effects on apoptotic factors ${ }^{19}$. Furthermore, ADP extracts directly translocate within the intra-nuclear space to induce downregulation of related genes ${ }^{20}$. Caglayan et al. (2019) also found that the apoptotic genes are expressed significantly in the kidney after MC administration ${ }^{21}$.

In the current study, the ADP treatment reduced Bax and p53 levels (while improving $\mathrm{Bcl} 2$ gene expression). According to the obtained results, it can be inferred that the ADP- based on positive antioxidant features- affects the molecular function and histological construction of hepatocytes. This property causes a diminished level of hepatic enzymes, boosted antioxidant capacity, and reduced NO levels. Indeed, MC with high mercury content can prompt a varied range of injuries, such as liver and heart diseases, allergy, and various side effects on hepatocytes (due to involvement of liver enzymes) ${ }^{22}$.

This study confirmed the morphological changes following MC administration, which included a significant increase in hepatocyte diameter and in the size of the central vein. Due to the therapeutic effects of $\mathrm{ADP}$, in all animals receiving $\mathrm{MC}+\mathrm{ADP}$ a significant decline was noticed on morphological changes, resembling a healthy organ. More differentiated microscopical features were also observed in the liver following MC administration; these features include hyper-perfusion in the space of tissue, inflammatory cell aggregation (especially macrophages) around the $\mathrm{CHV}, \mathrm{CHV}$ dilatation, and infiltration of lymphoid cells within the portal space. Based on a histological rule, in any kind of organ inflammation or injury, the macrophages exocytose the chemical intermediates to regulate tissue injury. 
Table 4: Effect of MC and ADP treatments on the liver levels of TNF $\alpha$, IL-1 $\beta$, and TLR4 ( $n=8$ for each group)

\begin{tabular}{lccc}
\hline Groups & TNF $\alpha(\mathrm{pg} / \mathrm{ml})$ & $\mathrm{IL}-1 \beta(\mathrm{pg} / \mathrm{ml})$ & TLR4 $(\mathrm{pg} / \mathrm{ml})$ \\
\hline Control & $78.85 \pm 6.6$ & $104.35 \pm 5.9$ & $53.97 \pm 3.5$ \\
MC $50 \mathrm{mg} / \mathrm{kg}$ & $146.64 \pm 8.4^{*}$ & $279.64 \pm 7.5^{*}$ & $148.04 \pm 8.3^{*}$ \\
ADP $30 \mathrm{mg} / \mathrm{kg}$ & $77.08 \pm 6.8$ & $101.82 \pm 4.4$ & $55.34 \pm 3.4$ \\
ADP $90 \mathrm{mg} / \mathrm{kg}$ & $79.64 \pm 7.3$ & $99.46 \pm 4.4$ & $51.82 \pm 4.1$ \\
ADP $270 \mathrm{mg} / \mathrm{kg}$ & $78.18 \pm 4.1$ & $105.07 \pm 7.1$ & $53.91 \pm 2.8$ \\
ADP+MC $30 \mathrm{mg} / \mathrm{kg}$ & $94.96 \pm 3.9$ & $161.11 \pm 8.8$ & $72.64 \pm 2.6$ \\
ADP+MC $90 \mathrm{mg} / \mathrm{kg}$ & $94.39 \pm 7.4$ & $142.94 \pm 6.2$ & $65.99 \pm 3.5$ \\
ADP+MC $270 \mathrm{mg} / \mathrm{kg}$ & $89.71 \pm 5.4$ & $137.73 \pm 5.6$ & $65.02 \pm 4.6$ \\
\hline
\end{tabular}

Data are presented as mean \pm SEM. ${ }^{*} \mathrm{P}<0.01$ compared to the control group. $\mathrm{P}<0.01$ compared to $\mathrm{MC}$ group. $\mathrm{P}<0.01$ compared to the MC group.

Abbreviations: MC: Mercuric chloride, ADP: Ashrasi Date palm.

In liver, the Kupffer cells are available in the sinusoidal space of the liver which can be stimulated in response to tissue damage, causing secretion of TNF- $\alpha$, IL- 1 and NO, thus leading to toxicity of liver and necrosis of cells ${ }^{23}$.MC is involved in extensive LP in hepatocytes. LP causes excessive cellular ROS and generation of free radicals. ROS and free radicals attack unsaturated fatty acids in cell membranes, causing protein alkylation ${ }^{24}$. ROS in elevated non-physiological levels change the three-dimension structure of the active site in hepatic enzymes and cause incomplete cell function, which eventually leads to necrosis. Necrosis triggers hepatic inflammatory responses that are followed by penetration of mononuclear inflammatory cells. Simultaneously, the cells that have died by the pathological process of necrosis release inflammatory chemical intermediates leading to hepatitis ${ }^{6}$. Our data is in agreement with Zhou et al. (2020) whose findings confirmed these pathological changes following MC administration ${ }^{7}$. The authors stated that MC in an acute process could actively induce necrosis, blood hyperperfusion, and increase TNF- $\alpha$ gene expression levels. MC was able to destroy the mitochondrial membrane in an indirect cellular pathway, thereby causing a flux of mitochondrial enzymes into the cytoplasm and decreased total antioxidant activity ${ }^{17}$. In oxidative stress onset and increased ROS/ Reactive Nitrogen Species (RNS) conditions, the mitochondrion is the predominantly damaged intracellular organelle 8 .

In this regard, it was documented that ADP can moderate LP processes in the cell cytosol and organelle membranes and also that it is able to increase total antioxidant capacity in hepatocytes (indicating a reduction in levels of oxidative stress) ${ }^{25}$. Thus, as a new finding, it is concluded that ADP, due to its antioxidant features, can moderate the level of LP into the normal state and increase the total antioxidant potential via inhibition of ROS production. As it was stated previously, based on histological assessments, the increased diameter of $\mathrm{CHV}$ is directly related to the cell necrosis after $\mathrm{MC}$ administration ${ }^{17}$. ADP via its antioxidant properties can inhibit glutathione reduction. In conclusion, the activation of antioxidant enzymes following ADP administration enables the cells to cope with the fatal effects of oxidative stress $^{26}$. Thus, it can be concluded that ADP as an exogenous agent regulates inflammatory pathways and inhibits the apoptosis process ${ }^{27}$. Saafi et al. (2011) reported, in an experimental study and based on histological assessments, that ADP has anti-cytotoxic effects against oxidative stress, which manifests these therapeutic effects on hepatocytes ${ }^{25}$. The outcomes of this study support the concepts of Mumtaz et al. (2019), which explain that liver damages and apoptosis initiation in hepatocytes can be produced via MC. ${ }^{28}$ Saryono et al. (2017) indicated that ADP reduces the MDA levels, which is in agreement with our findings ${ }^{29}$.

In this study, the results revealed a significant increase in liver enzyme activity in the MC group. Furthermore, for members of the ADP $+\mathrm{MC}$ group, a reduction trend was shown in the liver enzymes levels in comparison with the MC group. Any disruption in the liver cell membrane causes the enzymes to be released into the bloodstream ${ }^{8}$. It seems that MC can induce destruction on the cell membrane through the inhibition of 1-4 respiratory chain complexes ${ }^{30}$. The results are in line with conclusions by Emanuelli et al. (1998) who showed that MC administration in rats for 7 days induces a diminished level 
of TAC and equally amplifies the action of liver enzymes $^{31}$.It seems that ADP administration prevents enzymatic leakage and LP, leading to stability of cellular membranes ${ }^{32}$. Martín-Sánchez et al. (2017), in an experimental investigation, showed that ADP with the membrane-stabilizing property could lead to a reduction of serum markers of damaged liver, which is in line with the findings of our current investigation $^{33}$. ADP by endoplasmic reticulum recruitment can cause cellular defense and anti-apoptosis properties $^{20}$.

The outcomes of this study revealed that MC has the potential to increase the serum levels of NO. Also, due to the beneficial effects of ADP, the serum level of NO was reduced in comparison with the MC group.

The two main effects of ADP on cells that were discovered in this study are its anti-inflammatory and antioxidant properties. In the mammalian body, NO is known as a free radical, interfering with physiological manners at abnormal levels ${ }^{6}$. Along with NO, the hydroxyl radical (superoxide anion) can also cause hepatotoxicity ${ }^{34}$. It has been proven that low-expression levels of inducible nitric oxide synthase (iNOS) can significantly reduce NO production in cells. Antioxidants disrupt the molecular process of enzyme activities involved in NO production (substrates, cofactors, and protein enzymes) ${ }^{18}$. The results of the study by Hassan et al. are in line with the results of our current study; they suggest that ADP causes the expression of HO-1 and calmodulin-calcium-dependent kinase4 protein, leading to NO-inducing lipopolysaccharide inhibition $^{35}$.

Moreover, our findings depicted a significant rise in the expression of inflammatory mediators/factors in the MC group. The relationship among NO levels and inflammatory factors has been demonstrated through lipopolysaccharide-induced lung damage in experimental animals ${ }^{36}$. Pro-inflammatory cytokines declined by ADP administration in allergic rhinitis patients ${ }^{37}$. Consequently, we suggest a common positive connection between the levels of NO, TLRs, and inflammatory cytokines. However, in the inflammation process, we should not ignore the crucial role of the cell types in the intercellular interchange among defined TLRs and pro-inflammatory cytokines. Similarly, in the case of MC-induced liver inflammation, we demonstrated a highly positive correlation between NO and the expression of TNF- $\alpha$, IL- $1 \beta$ and TLR4. As a new finding, we observed that ADP reduces this unstable position. Moreover, Jalili and colleagues defined the collaboration among TNF$\alpha$, TLR- 4 and IL- 6 in protection cascade induced by Acacetin through antioxidant regulation in hepatitis and subsequent ischemia-reperfusion ${ }^{17}$. The current study is unique in that we show the relation of IL- $1 \beta$ and TLR- 4 or their dependence in the case of MC administration and ADP inflammation salvage.

\section{CONCLUSION}

The present study demonstrated in rats the hepatoprotective properties of the hydro-alcoholic extract of ADP, in contrast to the observed MC-induced liver destruction. ADP administration was found to reduce ROS, inflammatory cytokines, cell apoptosis, expression of $p 53$ and Bax genes, activation of antioxidant agents, and detoxification enzymes. Therefore, ADP should be considered as a therapeutic agent to recover the functional and histological characteristics of hepatocytes exposed to MC-induced damage. The protective effect was mediated through the antioxidant properties of the ADP extract. Overall, ADP shows great potential as a substitute beneficial agent against oxidative damages induced by toxic materials.

\section{ABBREVIATIONS}

ADP: Ashrasi Date palm

AI: Apoptotic index

ALP: Alkaline Phosphatase

ALT: Alanine Aminotransferase

AST: Aminotransferase

CHV: Central hepatic vein

EDTA: Ethylene diamine tetra-acetic acid

FRAP: Ferric Reducing Ability of Plasma

HD: Hepatocytes diameter

IL-1 $\beta$ : Interleukin 1 beta

LP: Lipid peroxidation

MC: Mercuric chloride

MDA: Malonaldehyde

ROS: Reactive Oxygen Species

TAC: Total antioxidant capacity

TBA: Thiobarbituric acid

TLR4: Toll-like receptor 4

\section{ACKNOWLEDGMENTS}

Kermanshah University of Medical Sciences' Research and Technology Deputy is gratefully acknowledged for the financial support for the research project.

\section{AUTHOR'S CONTRIBUTIONS}

MRS, SHR, AA performed the experiments, analyzed data and drafted the manuscript. MRS, SHR suggested the idea, explained the data, corrected the manuscript. All authors approved the final manuscript. 


\section{FUNDING}

Research Council of Kermanshah University of Medical Sciences.

\section{AVAILABILITY OF DATA AND MATERIALS}

Data and materials used and/or analyzed during the current study are available from the corresponding author on reasonable request.

\section{ETHICS APPROVAL AND CONSENT TO PARTICIPATE}

Not applicable.

\section{CONSENT FOR PUBLICATION}

Not applicable.

\section{COMPETING INTERESTS}

The authors declare that they have no competing interests.

\section{REFERENCES}

1. Bursal E, Aras A, Kılıç Ö, Buldurun K. Chemical constituent and radical scavenging antioxidant activity of Anthemis kotschyana Boiss. Nat Prod Res. 2020;6:1-4. PMID: 32028798. Available from: https://doi.org/10.1080/14786419. 2020.1723089 .

2. Hosseinipour M, Goodarzi N, Bakhtiari M. Protective efficiency of Ashrasi date palm hydroalcoholic extract against diabetesinduced testicular toxicity: A biochemical and stereological study. Andrologia. 2019;51(11):e13420. PMID: 31599021. Available from: https://doi.org/10.1111/and.13420.

3. Alothman OY, Alrashed MM, Anis A, Naveen J, Jawaid M. Characterization of Date Palm Fiber-Reinforced Different Polypropylene Matrices. Polymers. 2020;12(3):597. PMID: 32151079. Available from: https://doi.org/10.3390/ polym 12030597.

4. Vayalil PK. Antioxidant and antimutagenic properties of aqueous extract of date fruit (Phoenix dactylifera L. Arecaceae). Jounal of Agricultural and Food Chemistry. 2002;50(3):610617. PMID: 11804538 . Available from: https://doi.org/10.1021/ jf010716t.

5. Rathore MS, Patel PR, Siddiqui SA. Callus culture and plantlet regeneration in date palm (Phoneix dactylifera L.): an important horticultural cash crop for arid and semi-arid horticulture. Physiology and Molecular Biology of Plants. 2020;26(2):391398. PMID: 32158143. Available from: https://doi.org/10.1007/ s12298-019-00733-w.

6. Salahshoor MR, Mohammadi MM, Roshankhah SH, Najari N Jalili C. Effect of Falcaria vulgaris on oxidative damage of liver in diabetic rats. J Diabetes Metab Disord. 2019;18(1):1523. PMID: 31275870 . Available from: https://doi.org/10.1007/ s40200-019-00385-3.

7. Zhou C, et al. Effects of subchronic exposure of mercuric chloride on intestinal histology and microbiota in the cecum of chicken. Ecotoxicol Environ Saf. 2020;188(1):920-927. PMID: 31685026. Available from: https://doi.org/10.1186/s12966019-0860-z.

8. Salahshoor MR, Roshankhah S, Hosseni P, Jalili C. Genistein Improves Liver Damage in Male Mice Exposed to Morphine. Chin Med J. 2018;131(13):1598-1604. PMID: 29941714. Available from: https://doi.org/10.4103/0366-6999.235117.

9. Ansar S, lqbal M. Protective effect of diallylsulphide against mercuric chloride-induced hepatic injury in rats. Hum Exp
Toxicol. 2016;35(12):1305-1311. PMID: 26825963. Available from: https://doi.org/10.1177/0960327116629723.

10. Koli S, Prakash A, Choudhury S, Mandil R, Garg SK. Calcium Channels, Rho-Kinase, Protein Kinase-C, and PhospholipaseC Pathways Mediate Mercury Chloride-Induced Myometrial Contractions in Rats. Biol Trace Elem Res. 2019;187(2):418424. PMID: 29785630. Available from: https://doi.org/10.1007/ s12011-018-1379-x.

11. Betti CBR, Pool-Zobel BL. Comparative studies on cytotoxic and genotoxic effects of two organic mercury compounds in lymphocytes and gastric mucosa cells of SpragueDawley rats. Environ Mol Mutagen. 1993;22(3):172-180. PMID: 8404877. Available from: https://doi.org/10.1002/em. 2850220310.

12. Ahmad S, Mahmood R. Mercury chloride toxicity in human erythrocytes: enhanced generation of ROS and RNS, hemoglobin oxidation, impaired antioxidant power, and inhibition of plasma membrane redox system. Environ Sci Pollut Res. 2019;5:1-3.

13. Liu B, et al. Protective effects of dietary luteolin against mercuric chloride-induced lung injury in mice: Involvement of AKT/Nrf2 and NF- $\kappa$ B pathways. Food Chem Toxicol. 2018;113(6):296-302. PMID: 30612358. Available from: https: //doi.org/10.1007/s11356-018-04062-5.

14. Jalili C, Roshankhah S, Jalali A, Salahshoor MR. Hepatoprotective activity of royal jelly on mercuric chloride-induced damage model in rats. J Rep Pharm Sci. 2019;8(2):181-189. Available from: https://doi.org/10.4103/jrptps.JRPTPS_27_19.

15. Treas GE, Evans WC. Pharmacognosy, 13th edn. Bailliere Tindall, London. 1989;p. 176-180.

16. Salahshoor MR, Abdolmaleki A, Jalili C, Roshankhah S, Ziapour A. Determination of histopathological and biomedical parameters in protective effects of Petroselinum crispum on hepatotoxicity induced by dichlorvos in male Wistar rats. Com Clin Path. 2020;2:1-9. Available from: https://doi.org/10.1007/ s00580-019-03087-7.

17. Jalili $C$, et al. Acacetin Alleviates Hepatitis Following Renal Ischemia-Reperfusion Male Balb/C Mice by Antioxidants Regulation and Inflammatory Markers Suppression. J Invest Surg. 2019;31(5):1-8. PMID: 31686554. Available from: https://doi. org/10.1080/08941939.2019.1656309.

18. Wang MJ, Huang HY, Chiu TL, Chang HF, Wu HR. Peroxiredoxin 5 Silencing Sensitizes Dopaminergic Neuronal Cells to Rotenone via DNA Damage-Triggered ATM/p53/PUMA Signaling-Mediated Apoptosis. Cells. 2020;9(1):22-28.

19. Sugiura $Y$, et al. Detection of Serum miRNAs Affecting Liver Apoptosis in a Periodontitis Rat Model. In Vivo. 2020;34(9):117-123. PMID: 31861721. Available from: https: //doi.org/10.3390/cells9010022.

20. Banu $\mathrm{H}$, et al. Gold and silver nanoparticles biomimetically synthesized using date palm pollen extract-induce apoptosis and regulate $\mathrm{p} 53$ and $\mathrm{BCl}-2$ expression in human breast adenocarcinoma cells. Biol Trace Elem Res. 2018;186(1):122134. PMID: 29552710. Available from: https://doi.org/10.1007/ s12011-018-1287-0.

21. Caglayan C, Kandemir FM, Yildirim S, Kucukler S, Eser G. Rutin protects mercuric chloride-induced nephrotoxicity via targeting of aquaporin 1 level, oxidative stress, apoptosis and inflammation in rats. J Trace Elem Med Bio. 2019;54:69-78. PMID: 31109623. Available from: https://doi.org/10.1016/j. jtemb.2019.04.007.

22. Houston HC. The role of mercury and cadmium heavy metals in vascular disease, hypertension, coronary heart disease, and myocardial infarction. Altern Ther Health Med. 2007;13(2):S128-133. PMID: 17405690.

23. Amouoghli-Tabrizi B. Protective effect of edible turmeric powder on early hepatic injury in diabetic rats. J Kashan Univ Med Scl. 2010;14(2):190-199. PMID: 27168751.

24. Almeer RS, et al. Ziziphus spina-christi leaf extract attenuates mercury chloride-induced testicular dysfunction in rats. Environ Sci Pollut Res. 2020;27(3):3401-3412. PMID: 31840221. 
Available from: https://doi.org/10.1007/s11356-019-07237-w.

25. Saafi EB, et al. Protective effect of date palm fruit extract (Phoenix dactylifera L.) on dimethoate induced-oxidative stress in rat liver. Exp Toxicol Pathol. 2011;63(5):433-441. PMID: 20359872. Available from: https://doi.org/10.1016/j.etp. 2010.03.002.

26. Alawi RA, Alhamdani MS, Hoheisel JD, Baqi Y. Antifibrotic and tumor microenvironment modulating effect of date palm fruit (Phoenix dactylifera L.) extracts in pancreatic cancer. Biomedicine \& Pharmacotherapy. 2020;121:109522. PMID: 31675539. Available from: https://doi.org/10.1016/j.biopha. 2019.109522.

27. Khan A, et al. Silicon-mediated alleviation of combined salinity and cadmium stress in date palm (Phoenix dactylifera L.) by regulating physio-hormonal alteration. Ecotoxicology and environmental safety. 2020;188:109885. PMID: 31704322. Available from: https://doi.org/10.1016/j.ecoenv.2019.109885.

28. Mumtaz $\mathrm{S}$, et al. The protective role of ascorbic acid in the hepatotoxicity of cadmium and mercury in rabbits. Environ Sci Pollut Res. 2019;26(14):14087-14096. PMID: 30852747. Available from: https://doi.org/10.1007/s11356-019-04620-5.

29. Saryono S, Rahmawati E, Hidayat Al, Hisni D, Proverawati A. Plasma Malondialdehyde and Vitamin E Levels after Date Palm Seeds (Phoenix dactylifera) Steeping Administration. Asian Journal of Clinical Nutrition. 2017;9:131-136. Available from: https://doi.org/10.3923/ajcn.2017.131.136.

30. Ben-Ozer EY, et al. Mercuric chloridedamages cellular DNA by a non-apoptotic mechanism. Mutat Res Genet Toxicol Environ Mutagen. 2000;470:19-27. PMID: 10986472. Available from: https://doi.org/10.1016/s1383-5718(00)00083-8.

31. Emanuelli T, et al. Effect of Mercuric chloridelntoxication and Dimercaprol Treatment on $\sigma$-Aminolevulinate Dehydratase from Brain, Liver and Kidney of Adult Mice. Pharmacol Tox- icol. 1998;79(3):136-143. PMID: 8884872. Available from: https://doi.org/10.1111/j.1600-0773.1996.tb00257.x.

32. Martín-Sánchez AM, Ciro-Gómez G, Sayas E, Vilella-Esplá J, Ben-Abda J, Pérez-Álvarez JA. Date palm by-products as a new ingredient for the meat industry: Application to pork live pâté. Meat science. 2013;93(4):880-887. PMID: 23314613. Available from: https://doi.org/10.1016/j.meatsci.2012.11.049.

33. Martín-Sánchez AM, Ciro-Gómez G, Vilella-Esplá J, PérezÁlvarez JA, Sayas-Barberá E. Physicochemical and sensory characteristics of spreadable liver pâtés with annatto extract (bixa orellana L.) and date palm co-products (phoenix dactylifera L.). Foods. 2017;6(11):94. PMID: 29109376. Available from: https://doi.org/10.3390/foods6110094.

34. Nikbakht $\mathrm{M}$, et al. The effect of CTB on P53 protein acetylation and consequence apoptosis on MCF-7 and MRC-cell lines. Adv Biomed Res. 2013;2(24):147-156. PMID: 23977652. Available from: https://doi.org/10.4103/2277-9175.108005.

35. Hassan WA, El-kashlan AM, Mohamed NA. Egyptian date palm pollen ameliorates testicular dysfunction induced by cadmium chloride in adult male rats. Journal of American Sciences. 2012;8(4):659-669.

36. Somasundaram V, Gilmore AC, Basudhar D, Palmieri EM, Scheiblin DA, Heinz WF, et al. Inducible nitric oxide synthasederived extracellular nitric oxide flux regulates proinflammatory responses at the single cell level. Redox boil. 2020;28:354-361. PMID: 31683257. Available from: https: //doi.org/10.1016/j.redox.2019.101354.

37. Boghdadi G, Ali A, Lotfy G, Abdulfattah M, Sorour S. Immunological markers in allergic rhinitis patients treated with date palm immunotherapy. Inflammation Research. 2012;61(7):719-724. PMID: 22456954. Available from: https: //doi.org/10.1007/s00011-012-0464-4. 